\title{
Grammatical Errors in English Narrative Writing Committed by Class XI Students of SMA Dwijendra Denpasar
}

\author{
Komang Satria Wirasa ${ }^{1}$, Ketut Artawa ${ }^{2}$, Made Ratna Dian Aryani ${ }^{3}$ \\ satria.wirasa@gmail.com \\ Udayana University, Denpasar 80114, Indonesia
}

\begin{abstract}
This research generally aims to provide a reference regarding the analysis of grammatical errors in students' English narrative essays. In particular, the purpose of this study is focused on describing the forms of grammatical errors and identifying the factors that cause grammatical errors made by the eleventh-grade students of SMA Dwijendra Denpasar in writing narrative texts. The method in this study is a descriptive method with a qualitative approach. Further, the data from this study were collected by using the simak and the interview method to obtain information about the forms and factors of errors in students' narrative writing. Furthermore, this research data was analyzed qualitatively based on the taxonomy of linguistic categories proposed by Dulay et al. (1982) which focused on the linguistic components of morphology and syntax. Meanwhile, the factors that cause language errors were analyzed by the theory proposed by Richard (1970). Then the analysis of this research is presented in an informal method. Based on the results of the study, the forms of grammatical errors of the students, include the morphological category such as; indefinite errors, cases of misuse of possessive forms, errors of using verbs for the third person singular, simple past tense errors, and past participle errors. Afterward, the syntax error categories such as; noun phrase errors, prepositional phrase errors, verb phrase errors, errors in the use of progressive tense where students replace the suffix '-ing' with simple verb forms, the suitability of the subject with other words and word order. In addition, Factors that influence the existence of grammatical errors in English narrative essays for class XI students of SMA Dwijendra Denpasar include the influence of elements or rules of mother tongue in the second language and errors made by the learner due to the complexity of the rules of the language he is studying, such as; cases of overgeneralization, neglect of the boundaries of language rules and errors in concept hypotheses.
\end{abstract}

Published by IJRP.ORG. Selection and/or peer-review under responsibility of International Journal of Research Publications (IJRP.ORG)

Keywords: Error Analysis, Factors of Errors, Grammatical Errors 


\section{Introduction}

The error of using language is a phenomenon that can be inherent in every aspect, both in written and oral form. Both children and adults who have mastered the language can make errors even though they use the language. In this case, the difference in language errors in a person can be seen based on the type and frequency of errors. One of the types of errors referred to the mastery of grammatical rules (grammatical competence) which then causes differences in the realization of language application (performance).

Language errors are simply interpreted as the use of language, both verbally and in writing, which deviates from the existing language rules and can be analyzed using certain methods. According to Dulay et al (1982: 277), the error is part of a conversation or composition that deviates from some standard norm (or selected norm). Meanwhile, Brown (2007: 257-258) divides language errors into language errors and mistakes. Language errors occur systematically because they have not mastered the correct language rules. Meanwhile, language mistakes are caused by the failure to realize the rules of the language that have been mastered. In this case, the mistakes made by students in learning a foreign language can be seen by emphasizing error analysis. Brown (2007: 218) explains that error analysis is a series of lessons learned from the mistakes of language learners. So it can be concluded that language errors are the use of language that deviates from the applicable language rules.

Based on the fact that the students have low writing ability, especially for high school students (SMA) is not a new problem faced in the world of education. In the same vein, Tarigan (1987: 12) also revealed that the quality of students' language learning outcomes is still not satisfactory. One of these can be seen in the analysis of errors in student writing conducted by Erlangga, Suarnajaya \& Juniarta (2019), which found forms of errors such as omissions such as my father* name is Sukaarta where the correct form is my father's name is Sukaarta. In this sentence, the student removes the marker or apostrophe's (possessive form) in the word father so that the sentence is not grammatically correct. In this case, the forms of errors seen by Erlangga, Suarnajaya, \& Juniarta (2019) can also occur in other students. Therefore, this analysis is important to make effective English teaching, which is focused on fostering students' narrative writing skills. And, with the analysis of language errors, it is hoped that it will provide many benefits, especially those related to learning English grammar.

\section{Theoretical Framework}

The theory used in this study is an elaboration of the opinions expressed by several experts, especially in the field of linguistic error analysis. The choice of theory is considered based on its relevance to the problem to be studied, namely the problem of grammatical deviations in high school students' English narrative essays.

\subsection{Error Analysis}

By looking at errors in students' language learning, Dulay et al. (1982: 146) classifies the area of language errors into four, namely: linguistic category, the taxonomy of surface strategy category, the taxonomy of comparative category, and taxonomy of communication effect category. Based on the context of this study which discusses errors in the realm of grammar, the taxonomic area that is used as a starting point is the taxonomy of linguistic categories, which focuses on the level of morphology and syntax. Moreover, according to Dulay et al. (1982: 146), error analysis in morphology and syntax is classified into grammatical elements.

According to Dulay et al (1982:146), the linguistic category taxonomy refers to the classification of language errors based on linguistic components or certain linguistic elements or constituents or based on both, which is influenced by a form of error. Furthermore, the linguistic components in question include phonology (pronunciation), syntax and morphology (grammar), semantics and lexicon (meaning and vocabulary), and discourse (style). In this case, the constituent includes language elements that are part of a larger unit. 


\subsection{The Factors Caused the Errors}

In the process of language learning, errors often occur, and the causes of these errors themselves vary. The following is a description of each cause along with examples of language errors according to Richard (1970), they are:

\section{A. Interlingual Factor}

The interlingual errors are caused by the influence of elements or rules of the mother tongue in the second language being studied. Language learners get influenced by their first language in the process of learning their second language (Richard, 1970: 3-4). This can be interpreted as the first cause that language errors are caused by the interference of the mother tongue or first language (L1) to the second language (L2) that is being studied. In other words, the source of the error lies in the difference between the L1 linguistic system and the L2 linguistic system.

\section{B. Intralingual Factors}

Errors that originate from intralingual mean that the error made by the learner are caused by the complexity of the rules of the language that they are studying. Thus, some students find it difficult to understand the rules. Due to a lack of understanding of the language being studied, students over-generalize, ignore the boundaries of language rules, incomplete application of rules, and errors in conceptual hypotheses in using the language (both written and spoken) they learn (Richard, 1970: 6).

\section{Research Model}

The method used by researchers in this study is a descriptive method with a qualitative approach. Bogdan and Biklen (1982:27) reveal that qualitative research is carried out to explore phenomena that cannot be quantified that are descriptive such as the process of a work step, understandings of a variety of concepts, characteristics of images, styles, layouts, culture, and so on. This approach and method were chosen under the consideration that the form of elaboration of the results of the analysis of this research will be presented descriptively, the method of describing the data as it is based on the research focus.

The type of data used in this study is qualitative data. In line with Mahsun (2019: 351), in language learning research, the type of data in the form of student work/assignments is one type of qualitative data. In this regard, the source of the data in this study refers to the English narrative writings of the eleventh grade Dwijendra High School students in Denpasar.

The instrument used in this study was the researcher himself. Bogdan and Biklen (1982:27) say that the 'key instrument' in qualitative research is the researcher himself. Another instrument used in this research is an interview guide which contains a list of questions to obtain information about the factors of errors made by students. Along with technological advances, researchers recorded the data that had been obtained using a laptop and Microsoft Office Word software.

In this study, the researcher used the simak method with note-taking techniques in collecting data. In this case, the researcher used the listening method to get information about the forms of errors in the students' narrative writing. Furthermore, the writer can use note-taking techniques to collect relevant information obtained from the informants. Another method used in this research is the interview method. In this study, the interview method was used to obtain information about the factors of errors made by students.

In this study, researchers analyzed the data by using descriptive methods to describe the forms and factors that influence errors in students' narrative essays. Furthermore, the technique is based on the explanation of 

language teachers which includes five stages, they are; collecting samples, identifying errors contained in the sample, classifying error forms, describes the error and evaluates the error.

The presentation of the results of data analysis in this study was carried out using informal methods. In addition, the data presented in an informal form means, the form of formulation in the research just using words (Sudaryanto, 1993: 57).

\section{Result and discussion}

As stated in the previous chapter, in looking at the forms of grammatical errors, this study applies the taxonomy of linguistic categories Dulay et al. (1982). In connection with the formulation of the problem in this study which discusses language errors at the grammatical level, the linguistic components that are the focus of this research are the morphological and syntactic components.

\section{A. Morphological Types of Errors}

In the morphological category error analysis, Dulay et al. (in Politzer and Ramirez, 1970) describe the forms of errors in the morphological category including; indefinite article errors, the use of possessive forms, third-person singular verbs, simple past tense forms, past participle forms, and comparative adjective/adverb forms. Furthermore, the findings of the forms of morphological category errors in students' English narrative writing are described as follows:

(1) a amusing

In data (1), students use the indefinite article 'a' followed by a noun that begins with a vowel sound. Based on the explanation of Kroger (2005: 288), the indefinite article is one of the allomorphic forms where the form of this article depends entirely on the phonological form of the word that follows it. Where the word amusing in data (1) begins with a vowel sound [ə], the word idea. Thus, the article 'a' in the sentence in data (1) is not under the existing English grammar. In this case, the correct sentence to correct the error is data (1) must be an amusing.

(2) Angela* story

Based on data (2), it can be seen that some students committed ownership markers (possessive -'s/-') on Angela's noun 'the name of the character in the story to explain the form of ownership of the story. In line with that, Fromkin et al (2003:101) explained that the affix -'s or apostrophe (-') is an inflectional morpheme that functions to express the meaning of possession (possessive -'s/-') in nouns. Errors in the form of omitting affixes -'s or apostrophes (-') in the data can be classified as errors, where students have not been able to use these rules and consistently make the same errors. This is reinforced by the statement of Brown (2007:258) that the form of systematic and consistent deviations made by students can be categorized as errors.

\section{B. Syntax Types of Errors}

Dulay et al (in Politzer and Ramirez, 1970) described the forms of errors in the syntax category including some constituents, such as; noun phrases, verb phrases, verb construction with other verbs, word order, and some forms of transformation. The following is a description of the forms of syntactic category errors in students' English narrative writing.

(3) His husband

(4) It nest (S17/P1/L6) (Repetition) it nest

Errors that are found in students' writing in the data above can be classified into the wrong form of using possessive adjectives. According to Parrot (2000: 371) that the use of possessive adjectives and pronouns 
should use the object pronoun her in the data (3) and the object pronoun its found in the data (4). When viewed from the results of interviews that have been carried out, this error can be categorized into error, afterwards, when the researchers asked questions about possessive adjectives the students still do not understand the appropriate form of possessive adjectives. In this case, the appropriate form to erode errors in the use of possessive adjectives is her husband and its nest.

(5) five big dogs are (*in) the pet shop

(6) the bear came near (*into) the one

Based on the data that had been collected, data (5) and (6) can be grouped into prepositional phrase errors, in this case, both the data (5) and (6) show the form of deleting prepositions to explain the place and purpose, which should exist to complete sentences. In this case, data (5) requires the preposition in as an adverb of the place for the noun phrase five big dogs 'five big dogs' that are (inside) the pet shop. As for data (6), the sentence requires the preposition into, where one of the functions of the preposition is to explain the direction of the goal of something. To correct the errors in the form of omitting prepositions, the sentences should be (5) five big dogs are in the pet shop and (6) the bear came near into the one.

(7) the boy (*went?) to the tree

The form of errors that appear in students' writing on data (7) can be classified into the form of omitting the main verb. In this case, there is no verb in the sentence. Referring to the context of the paragraph, the appropriate verb is an activity verb that can explain the subject of going to someone/something. So that the verb go/went is considered appropriate to complete the sentence in the narrative story. Therefore, the form is following English grammar, so data (7) becomes the boy who went to the tree.

(8) Rabbit thought this (*was) good joke

(9) He (*was) eager to have...

The form of errors that appear in students' writing on data (8) and (9) can be classified into the form of omitting the main verb to be, where there is not a single verb, in this case, to be in the sentence. Parrot (2000:308) explains that many languages (including most of the Middle East and Asia) do not require a verb to connect the subject and complement. So that there is language interference, where some students or speakers of English as a foreign language omit the be the form or connecting verbs because of their mother tongue factor. Referring to the context of the sentence, the verb be is used to explain the noun phrase good joke (8) and the adjective eager (9). So that the appropriate be verbs in the sentence are (8) Rabbit thought this was good joke and (9) He was eager to have...

(10) how gorgeous you are look* today

Errors that appear in students' writing on data (10) can be classified into the omission of one part or element in a sentence. In this case, students omit the -ing affix as a marker of progressive tense inflection. In line with that, Parrot (2000:176) explains the progressive tense sentences are characterized by auxiliary verbs (such as am, is, were, have been, etc.) and the main verb in this form is added with the suffix -ing. Therefore, the sentences they make are grammatically wrong. In addition, the correct form of sentence to correct these sentences is how gorgeous you are looking today.

(11) the line finish

The rules for forming noun phrases in English, adjectives are present as a pre-modifier to explain the main noun, even when a noun is used to describe another noun, the noun is still considered an adjective. However, data (11) showed that students place adjectives after the main noun, so the noun phrases they produced are not following the rules of English grammar. In addition, to correct the form of student errors 


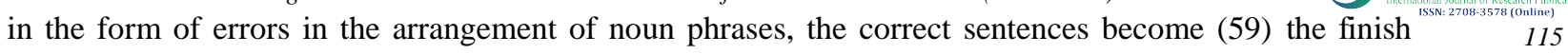

line, (60) bright idea, and (61) apple tree.

\section{The Factors Caused Errors}

After knowing the grammatical errors forms committed by students, it is essential to know the factors that caused grammatical errors in students' English narrative writing. According to Richards (1970), these factors are divided into two, namely, in terms of interlingual and intralingual.

\section{(1) Interlingual}

One of the factors that may cause the inappropriate use of grammar rules in the target language (English) is the interlingual factor or some researchers call it first language interference.

(a) The line finish

(b) "...while the dog sleep*..."

(c) Idea bright

Based on the data (1), (2), and (3) presented above, it shows that students do not use English grammar rules well. In this case, students translate Indonesian patterns to form noun phrases and remove the suffix $-\mathrm{s} /$ es which should be attached to infinitive verbs to form the simple present tense for singular third-person pronouns. So the error can be considered as an interlingual error. In English noun formation rules, adjectives are present as a pre-modifier to describe the main noun, even when a noun is used to describe another noun, the noun is considered an adjective. Whereas in Indonesian, the main noun comes before the adjective it describes. Furthermore, Bay (2018:75) explains that in the English rules, verbs that follow the third-person subject must add the morpheme $-\mathrm{s}$ or $-\mathrm{es}$, but Indonesian is not. In Indonesian grammatical rules, a sentence that has a verb or predicate does not recognize additional morphemes.

\section{(2) Intralingual}

Errors that originate from intralingual means that the errors made by the learner are caused by the complexity of the rules of the language that they are studying so that some students find it difficult to understand the rules.

\section{a. Overgeneralization}

The case of overgeneralization occurs when learners create deviant structures based on their experience of other structures in the target language (Richard, 1970: 8).

(d) an $\operatorname{pack}(\mathrm{S} 1 / \mathrm{P} 3 / \mathrm{L} 1)$

a amusing (S16/P1/L9)

Some students generalize the use of indefinite articles. In this case, students committed a morphological category error in the form of using the article 'an' to replace the article 'a' before the word with a consonant prefix (in case of 4a) and vice versa, the article 'an' which was replaced by the article 'a' before words with a vowel prefix (in case $4 \mathrm{~b}$ ). Based on the results of the interviews that have been conducted, the students explained that they did not understand the difference between articles a and an and generalized the rules of both articles.

b. Ignorance of Rules Restriction

Ignoring the boundaries of language rules occurs when students ignore the boundaries of existing rules and some do not follow the applicable rules (Richard, 1970: 9). 
Some students make some errors in using articles. In this case, the students committed the mistake of omitting the article 'a' at the beginning of the noun phrase big dog. If seen from the results of the interview, the student still does not understand the use of articles by ignoring the rules for using good articles as markers in the title of the story.

c. False concept hypothesized or fossilized

Errors in the concept hypothesis are caused because the speaker misunderstands a concept or language rule, this is often referred to as misguided (Richard, 1970: 14).

(f) Sura were the name... (S6/P1/L2)

Sura and baya was looking... (S6/P2/L1)

Data (6a) and (6b) can be classified into errors in the concept hypothesis where the auxiliary verb 'were' is used for the singular subject and conversely the auxiliary verb 'was' is used for plural subjects in a sentence. Based on the explanation from Parrott (2000:219), the pronoun I/she/he/it (singular) uses the auxiliary verb 'was'. Meanwhile, we/you/they (plural) uses the auxiliary verb 'were' in past tense sentences (grammatical features in narrative writing). In this case, students can apply the verb was/were, but there is a slight error where the verb is applied to the wrong subject. Based on the results of interviews conducted, students who made errors in the data (16) and (17) assumed that the verb was can be used for a single subject and vice versa, the verb was used for a single subject.

\section{Conclusion}

Based on the results and discussions that have been described previously, the forms of grammatical errors in English narrative essays committed by the class XI students of SMA Dwijendra Denpasar were morphological category errors, they are; indefinite article errors (eg, article 'a' is used to replace the article 'an' before a word with a vowel prefix, and vice versa, article 'an' is used to replace article 'a'), cases of using the possessive form of error (eg, deleting possession marker affixes -'s or apostrophes -'), errors in the use of third-person singular verbs (eg. failure to attach '-s'), simple past tense errors (eg, deletion of '-ed', regularization by adding '-ed' and substitution of the simple non-past) and Past participle misformation (eg, Omission of the -ed affix). In addition, it also includes syntax error categories including the noun phrase errors (eg. the omission of articles, incorrect use of possessives, quantifiers, and use of pronouns) prepositional phrase errors (eg. the omission of propositions and misuse of prepositions), verb phrase errors (eg. omission of main verbs, omission of 'to be'), errors in the use of progressive tense where students replaced the affix '-ing' with a simple verb form, the suitability of the subject with other words ( eg, the discrepancy between subject and adverb of number and discrepancy between subject and tense) and word order (eg, changing adjectives that are placed after the noun).

Also, some factors influence the existence of grammatical errors in English narrative essays for class XI students of SMA Dwijendra Denpasar including, the influence of elements or rules of the mother tongue in the second language being studied or interlingual and errors that were committed by learners due to the complexity of the language rules used being studied or intralingual, which includes; cases of an overgeneralization, neglect of the boundaries of language rules, and errors in concept hypotheses. 
Bay, I.W. 2018. Interferensi Gramatikal Bahasa Indonesia dalam Penggunaan Bahasa Inggris. Yogyakarta: Zahir Publishing.

Brown, H.D. 2007. Teaching by Principles: An Interactive Approach to Language Pedagogy ( $7^{\text {th }}$ ed). New York: Longman.

Erlangga, I.P.B., Suarnajaya, I.W., \& Juniarta, P.A.K. 2019. An Analysis of Grammatical Errors Made by The Seventh Grade Students of SMP Negeri 2 Sukawati In Writing Descriptive Texts in The Academic Year 2018/2019. LEJU, 2(1), 19-29.

Dulay, H., Burt, M., \& Krashen, S. 1982. Language Two. New York: Oxford University Press.

Richards, J.C. 1971. A Non-Contrastive Approach to Error Analysis. A Paper presented in TESOL, San Francisco, California. https://www.professorjackrichards.com.

Bogdan, R. C., \& Biklen, S. K. 1982. Qualitative Research for Education: An Introduction to Theory and Methods. USA: Allyn Bacon Inc.

Mahsun. 2019. Metodologi Penelitian Bahasa: Tahap Strategi, Metode dan Tekniknya (3 ${ }^{\text {rd }}$ ed). Depok: PT Raja Grafindo Persada.

Kroeger, P.R. 2005. Analyzing Grammar: an Introduction. Cambridge: Cambridge University Press.

Parrot, M. 2000. Grammar for English Language Teachers ( $2^{\text {nd }}$ ed). Cambridge: Cambridge University Press. 